\title{
Towards Innovation in Multinational Corporation Subsidiaries: Development of an Instrument to Select and Evaluate Value Driven Strategies
}

\author{
Sinead Corry ${ }^{1}$ and Kathryn Cormican ${ }^{1^{*}}$
}

\begin{abstract}
This paper examines the complex, interdependent relationship between multinational companies and their subsidiaries. It discusses how subsidiary role development and specific strategic initiatives may add new value to corporations. While previous studies have identified the need for more proactive management practices, there are few practical guides available to managers to help them improve their performance. This paper addresses this deficit and contributes new knowledge on subsidiary role development practices in terms of selection and evaluation. Through an in-depth analysis of extant literature, the research developed and tested an instrument that allows decision makers to assess their company against good practice. This instrument (or audit tool) is an accurate, reliable and valid mechanism to measure a subsidiary's role development strategies.
\end{abstract}

Keywords: Multi-national corporation; subsidiary; strategy selection and evaluation; best practice analysis; scorecard

Submitted: Jun $14^{\text {th }}, 2018 /$ Approved: March 22 $2^{\text {nd }}, 2019$

\section{Introduction}

Subsidiaries of multinational companies (MNCs) play a vital role in the modern economy. A subsidiary can be defined as "any operational unit controlled by the multinational company and situated outside the home country" (Birkinshaw, 1997, 207). Bouquet and Birkinshaw (2008a) showed that while subsidiaries are dependent on their corporate parent they also have sources of power and influence. The conventional belief of viewing the foreign subsidiary as a subordinate entity within the MNC has been the subject of continuing debate in management literature. Many researchers argue that managing a subsidiary effectively is not simply about carrying out the narrow mandate prescribed by the parent; but rather it is about fulfilling the current mandate in a superior way and pursuing strategic initiatives that add new value to the corporation (Delany, 2000). In this regard, subsidiaries become innovators in a fully integrated network (Di Minin and Zhang, 2010). Cantwell and Mudambi (2005) refer to this as a "competence-creating" role.

Subsidiary role development has been described by researchers "as a change in the product, value-added and market scope of a subsidiary" (Dörrenbächer and Gammelgaard, 2006, p. 267). The development of the role of a subsidiary has also been described as moving from "doing only what is expected" to "doing what also makes good business sense" (Sargeant, 1990, as cited in Delany 2000, p. 227). Researchers have investigated this advancement and generated typologies to help our understanding in this regard (Hansen et al., 2011; Delany, 2000). For example, Delany's (2000) research proposed an eight stage model for advancing the development of a subsidiary from fulfilling a basic mandate through to that of a strategic independent entity. Thus the subsidiary develops by building on previous achievements such that each step is a progression of the existing mandate. Progression through each of these stages demands that the subsidiary consciously and proactively develop a strategy to add value. Some of these strategies include value chain migration (Fennelly and Cormican, 2006), initiative taking (Birkinshaw and Fry, 1998; Delany, 2000; Tseng et al., 2004), courting headquarters attention (Birkinshaw et al., 2006; Bouquet and Birkinshaw, 2008b), embedding itself within the multinational company (Heidenreich, 2012), gaining autonomy from headquarters (Paterson and Brock, 2002), and subsidiary entrepreneurship (Birkinshaw, 1997; Scott et al., 2010).

While the literature details diverse approaches that can be taken in order to develop the role of the subsidiary we find that much of this is prescriptive. We argue that it is essential to adopt a more open and discursive approach in order to explore and improve current practices. In reality, organisations require an integrated suite of options that they can tailor to their needs. In light of this our study seeks to understand current work practices in real world operational settings that promote value adding strategies. The research is descriptive rather than prescriptive. We provide narratives of the value added practices and derive an explanatory framework to enable a more empirical analysis of these practices. Thus the main contribution of this paper is the development of an instrument that can be used to allow organisations to assess themselves against good practice as defined by the literature. As the underlying framework is explanatory rather than categorical we describe practices and perspectives that overlap as well as interact. In other words, best practice items are presented for analytic clarity and convenience rather than as an ontological separation. The instrument is them validated for levels of accuracy, validity and reliability by a sample of 108 respondents. Findings from this analysis are presented.

\section{Initiatives to add value}

According to Schmid et al., (2014), subsidiary initiatives are proactive, autonomous and risk-taking activities that originate outside the home country in a foreign subsidiary of a Multinational Corporation

(1) College of Engineering \& Informatics, National University of Ireland, Galway,

University Road, Galway, Ireland H91 TK33

*Corresponding author: kathryn.cormican@nuigalway.ie 
(MNC). These value driven initiatives are taken in order to advance or evolve the role of the subsidiaries. They are, by definition, entrepreneurial activities. These efforts can strengthen the subsidiary mandate within the MNC network by means of value-adding activities. This can lead to greater autonomy for the subsidiary resulting in control over the development of new products, manufacturing process, penetration of new markets or simply the generation of new ideas that have applications for other parts of the global organisation.

However, subsidiary initiative taking was recently labelled a "troublesome and little-understood concept" (Ambos et al., 2010, p.1100). The literature also provides evidence of intra-organizational conflict between headquarters and subsidiaries concerning the issue (Blazejewski and Becker-Ritterspach, 2011; Schotter and Beamish, 2011). Some studies have found that subsidiary managers' motives and interests are not necessarily aligned with those of the MNC (Ambos and Schlegelmilch, 2007; Boussebaa, 2009). In other words, subsidiaries may seek to advance their role in such a way that it conflicts with the overall strategy of the MNC. In light of this, obstacles may lie in the path of subsidiaries who try to pursue new initiatives. It has been noted that local initiatives can be either applauded or condemned by headquarters as oftentimes initiatives are seen as empire building. To this end Birkinshaw and Fry (1998) state that the "combination of outright opposition, internal competition, and passive indifference are a challenging set of obstacles for the initiative champions" (Birkinshaw and Fry 1998, p. 54). Consequently, it may be challenging to ensure that essential and sufficient resources are available to implement their strategies.

Many studies have examined initiative taking as a means of achieving the added value required for subsidiaries to progress in their role (Hansen et al., 2011; Wang and Suh, 2009). Suggested approaches to increasing the legitimacy of the subsidiary can be categorised under two broad approaches; (a) enhancing the subsidiaries profile and (b) pursuing new opportunities. Enhancing the profile focuses on improving credibility, image and reputation within the MNC and showcasing the unique factors of the subsidiary. Identifying and pursuing new opportunities may include developing new products and processes, moving into strategically important markets and establishing collaborative partnerships with other peer subsidiaries (Bouquet and Birkinshaw, 2008). Conducting research and development is a highly regarded method of securing role development. Mudambi et al., (2007) established the link between research and development output, as calculated by the number of patent citations and "increased subsidiary self-determination and enhanced teamwork" (Mudambi et al., 2007 p. 453). Delany (2000) concurs with this view, asserting that the multinational company will benefit from supporting and facilitating initiative taking at the subsidiary as it maximises the benefits of its skills and expertise. However, he warns that subsidiary initiative taking is only a successful long-term strategy for the subsidiary if it results it value-added activities contributing to the operations of the parent MNC. Reilly et al., (2012) also believe that subsidiaries should align their initiatives with the strategy being pursued by headquarters. This maximises transparency between headquarters and the subsidiary ensuring trust and confidence is developed. Thus a "mutually interdependent relationship is enabled which facilitates incremental subsidiary growth" (Reilly et al., 2012, p. 9).

There is no consensus among researchers as to the best way to pursue subsidiary initiative taking in order to secure role development and high value added activities however several schools of thought exist on how to pursue it. After a synthesis of the literature we identified four potential strategies for subsidiary role development. These factors are descriptive and explanatory and are not mutually exclusive. Thus when considered together they form the basis of an integrated framework to guide practitioners in their quest to advance or evolve their role.

\section{Fulfil the mandate}

Paterson and Brock, (2002) assert that mandates of MNC subsidiaries have evolved as a distinct field of research and many studies have been conducted in this domain. For example, Zeschky et al., (2014) examine the types and levels of mandates in a MNC environment while Hansen et al., (2011) empirically investigate the evolution of mandate trajectories in developing economies. Many studies explore how the host country environment shapes mandates of subsidiaries (Bevan et al., 2004; Luo, 2005). More recently Sofka, et al., (2014) have considered how knowledge is protected in this environment.

Mitchell et al., (1997) posit that "power, legitimacy and urgency" are important to ensure that subsidiaries are seen as worthy of attention. Fulfilling a mandate well helps a subsidiary to achieve legitimacy and is a powerful tool in role development. The literature contends that subsidiaries should fulfil the mandate specified by headquarters to the very best of their ability (Hansen, et al., 2011; Reilly et al., 2012). For example, Birkinshaw et al., (2006) state that it is important to "be a good citizen" and delivering what is required is a good way of achieving this. Reilly et al., (2012) takes this a step further and states that not only should subsidiaries fulfil the mandate but they should ensure that they are compliant with the strategy of headquarters and pursue all opportunities that align with this strategy.

However, fulfilling the mandate and maintaining compliance with headquarters' mandate while important is not sufficient to ensure role development. Researchers emphasise the importance of finding ways of taking control; this involves finding ways of working outside of the formal structure of the multinational company and involves a higher levels of risk (Bouquet and Birkinshaw, 2008a). Fennelly and Cormican (2006) explored value chain migration in Irish medical device companies. Their work described "charter extension" as a method of role development; they found that in order to achieve this, the subsidiary must not only do the job assigned to them but also be proactive in making headquarters aware of their key capabilities and skills.

\section{Leadership}

The literature provides evidence to suggest that there is often tension or conflict between leadership in the subsidiary and leaders in headquarters in the MNC (Blazejewski and Becker-Ritterspach, 2011; Boussebaa, 2009). However, Schotter and Beamish, (2011) assert that 
research has "struggled to acknowledge the magnitude and complexity of intra-organizational conflict coordination" and the "roles that individual managers play" (Schotter and Beamish, 2011, p. 243). Leaders in the subsidiary are often motivated to evolve the role of the subsidiary into a more innovative and value adding entity (Ambos and Schlegelmilch, 2007) while leaders in the headquarters are eager to ensure that subsidiaries concentrate on fulfilling their mandate.

To move towards value adding initiatives it is imperative that managers shift their mind-set from one of subservience to the corporate headquarters to one of initiative taking in order to exploit its importance within the multinational company network (Delany 2000). Birkinshaw and Fry (1998) found that subsidiaries that are successful in developing new roles have a champion with the talent to identify this business opportunity and drive it forward. Many other authors suggest that leaders should adopt an entrepreneurial perspective and become catalysts for change (see Garcia-Pont et al., 2009; Yamin and Andersson, 2011). To this end the literature provides evidence to show that leaders in subsidiaries have forged independent relationships within and beyond the corporate network to explore and exploit potential innovative opportunities (Di Minin and Zhang, 2010; Schotter and Beamish, 2011; Jindra, et al., 2009). Other entrepreneurial leaders have developed ideas using subsidiary resources without headquarters knowledge and then presented these developments to headquarters once they have demonstrated their viability (Birkinshaw and Fry, 1998; Delaney, 2000).

\section{Attention seeking}

Subsidiaries must publicise their strengths and capabilities to headquarters in order to gain attention. Researchers have looked at how to attract attention or sell issues to management (Dutton and Ashford, 1993) and the importance of this communication to the strategic direction of the multinational company and the overall competitiveness (Dutton et al., 1997). The relationship between the subsidiary and headquarters is essential in gaining attention for the subsidiary. Strategic isolation is often a problem for subsidiaries which are based far from headquarters and whose abilities do not form a strategically important part of the value chain or are not in a strategically important section of the value chain (Bouquet and Birkinshaw, 2008b).

Birkinshaw et al., (2006) categorised attention as a resource into three groups "top down or bottom up", "directive or supportive" and "instrumental". Top down or bottom up is a straightforward method of communication, either it is sought by subsidiary management (bottom up) or is part of the formal review structure, e.g. annual reviews, metrics (top down). Directive or supportive refers to the extent to which the headquarters may be looking to learn about the subsidiary (supportive) or due to concerns it may have (directive). Instrumental refers to internal communications, and symbolic refers to communications to stakeholders. Birkinshaw et al., (2006) posit that bottom up, supportive and symbolic are the types of attention that a subsidiary should strive to achieve.
It is important to note that the overarching goal of attention seeking is to gain an advantage rather than having an adverse effect on the subsidiary. Bouquet and Birkinshaw (2008b) noted that excessive attention can have a negative impact, leading to an overestimation of the performance of the subsidiary and placing an unnecessary burden on resources. Ambos et al., (2010) found that in order to succeed, subsidiary initiatives required attention, however this attention in turn negativity affected the autonomy of the subsidiary. Although overall, pursuing initiatives seems to be more beneficial to the subsidiary than staying below the radar.

\section{Autonomy}

Birkinshaw and Hood, (1998) posit that subsidiaries should have some level of autonomy over their decision making and resources. However, in practice, different types of subsidiaries enjoy different levels of autonomy (Persaud, 2005). Zeschky et al., (2014) propose a typology that identifies four levels of autonomy in R\&D subsidiaries. They argue that the degree of technology and market orientation influences the type of mandates and level of autonomy. According to Young and Tavares, (2004) the level of autonomy experienced by the subsidiary depends on the degree to which decision making is centralized. While the subsidiary seeks for more autonomy oftentimes the $\mathrm{MNC}$ is eager to maintain a tight control over decisions and resources as they fear that too much autonomy will lead to empire building and maverick management teams pursuing pet projects that do not align with corporate strategy (Paterson and Brock, 2002).

Other researchers link the level of autonomy granted to trust between the subsidiary and headquarters. This trust is usually gained by fulfilling a mandate well (Bouquet and Birkinshaw, 2008a; Delany, 2000; Mitchell et al., 1997). Tavares and Young (2006) assert that subsidiaries can develop and leverage distinct capabilities and thereby alter their role and mandate within the MNC organization.

\section{Research Methodology}

\section{Developing the instrument}

A deductive methodology was used in this study in order to provide an empirical estimate of each theoretical determinant. The approach taken to developing the instrument was based on that used by Voss et al., (1994) and DeVellis (2012). This process begins with the development of a model that is grounded in best practice literature and then operationalizing this through specific tangible items that can assess current versus best practice. Worthington and Whitaker, (2006) posit that it is inherently difficult to measure that which is ill-defined therefore it was essential to start with a clear conceptual understanding of our model. This model of value adding strategies was developed using a top down approach. It comprised a detailed synthesis of the relevant literature which enabled us to identify and classify four core elements from the overall conceptual framework i.e. (a) Fulfilling the mandate, (b) Leadership, (c) Attention seeking, (d) Autonomy. Subsequently a bottoms-up approach was used to develop specific statements which characterised best practice in each of the categories based on the literature (Chisea et al., 1996; Voss et al., 1994). Table 1 presents 
these statements. Likert-type scales are one of the most commonly used item formats in to gauge levels of agreement with an item (DeVellis, 2012; Allen and Seaman, 2007). Consequently this was employed in our study in order to allow potential respondents to assess the level of importance for each item. In order to avoid extremes and to allow for a greater differentiation a five point Likert scale was used to assess the extent to which an individual agrees or disagrees with each statement.

Table 1: Items on the scorecard

\begin{tabular}{|c|c|}
\hline Item measured & Supported by \\
\hline $\begin{array}{l}\text { The subsidiary does not just what is expected by headquarters but what makes bu- } \\
\text { siness sense }\end{array}$ & $\begin{array}{l}\text { Achcaoucaou et al., 2014; Bouquet and Birkinshaw, 2008a; Bevan et al., } \\
\text { 2004; Luo, 2005; Sargeant, } 1990\end{array}$ \\
\hline The subsidiary fulfils the mandate of the company e.g. manufacturing excellence & Reilly et al., 2012; Hansen, et al., 2011; Mitchell et al., 1997 \\
\hline $\begin{array}{l}\text { Headquarters recognise the subsidiary for its potential contribution to innovation } \\
\text { and new ideas }\end{array}$ & Fennelly and Cormican, 2006; Birkinshaw and Hood, 2001 \\
\hline The subsidiary delivers on its key responsibilities & Reilly et al., 2012; Fennelly and Cormican, 2006, Mitchell et al., 1997 \\
\hline The subsidiary's leadership team defines the local strategy & Birkinshaw et al., 2006; Delany 2000 \\
\hline $\begin{array}{l}\text { The subsidiary's leadership team spends significant time building relationships } \\
\text { within and beyond the corporate network }\end{array}$ & $\begin{array}{l}\text { Schotter and Beamish, 2011; Di Minin and Zhang, 2010; Jindra,et al., 2009; } \\
\text { Cantwell and Mudambi, 2005 }\end{array}$ \\
\hline The subsidiary's leadership team acts in an entrepreneurial way and is a catalyst for change & Yamin and Andersson, 2011; Garcia-Pont et al., 2009 \\
\hline $\begin{array}{l}\text { The initiatives pursued by the subsidiary's leadership team at the subsidiary add } \\
\text { value to the organization as a whole }\end{array}$ & Reilly et al., 2012; Delany, 2000 \\
\hline The subsidiary's leadership visits other corporate sites in the network & Delany, 2000 \\
\hline $\begin{array}{l}\text { The subsidiary's leadership team pursues initiative taking rather than solely imple- } \\
\text { menting headquarters defined strategies }\end{array}$ & $\begin{array}{l}\text { Yamin and Andersson, 2011; Garcia-Pont et al., 2009, Birkinshaw et al., } \\
2006\end{array}$ \\
\hline The subsidiary is proactive in making headquarters aware of its key capabilities and skills & Fennelly and Cormican, 2006 \\
\hline $\begin{array}{l}\text { The subsidiary's leadership team looks for attention from headquarters in order to } \\
\text { gain an advantage }\end{array}$ & Birkinshaw et al., 2006; Dutton et al., 1997 \\
\hline $\begin{array}{l}\text { The subsidiary's leadership team designs strategies that allow the subsidiary to in- } \\
\text { fluence the amount and type of attention they receive from headquarters }\end{array}$ & Birkinshaw et al., 2006, Dutton et al., 1997 \\
\hline $\begin{array}{l}\text { The subsidiary works outside the formal structure of the multinational company e.g. } \\
\text { projects are implemented without formal reviews from headquarters }\end{array}$ & Ambos et al., 2010; Bouquet and Birkinshaw 2008 \\
\hline $\begin{array}{l}\text { Resources are made available by the subsidiary's leadership team to allow initiative } \\
\text { taking by employees }\end{array}$ & Birkinshaw et al., 2006 \\
\hline The subsidiary has a high level of autonomy over its decision making & Zeschky, et al., 2014; Birkinshaw et al., 2006; Young and Tavares, 2004 \\
\hline $\begin{array}{l}\text { The subsidiary has control over key strategic decisions for particular activities (e.g. } \\
\text { R\&D, manufacturing, marketing) in the value chain }\end{array}$ & Jindra, et al., 2009; Birkinshaw et al., 2006; Young and Tavares, 2004 \\
\hline Autonomy is targeted as an important goal for the subsidiary & Ambos et al., 2010; Birkinshaw et al., 2006 \\
\hline
\end{tabular}




\section{Face Validity}

Validity is the primary concern in developing items for instruments. Items or statements must reflect the instruments intent (DeVellis, 2012). Poorly worded items may introduce possible sources of error variance (Worthington and Whitaker, 2006). Face validity is particularly important for unexamined scale items in particular such as ours (Hardesty and Bearden, 2004). Face validity is a subjective test which attempts to assess the extent to which an instrument actually measures the concept it purports to measure. In other words, it reviews the relevance of a test as it appears to test participants. It is lauded to have merit even though it is very subjective (Haladyna, 2004; DeVon et al., 2007). Consequently, a pilot study was conducted with experts in the area. This involved assessing the relevance and appropriateness of the proposed instrument as well as the grammar, syntax, organization, and logical flow (after DeVon et al., 2007; DeVellis, 2012). Suggestions for improvement were incorporated and edits were made to the instrument as a result.

\section{Content Validity}

Voss et al., (1994) state that content validity as an important consideration when assessing tools such as audits and scorecards. Content validity measures the degree to which a sample of items or statements, when taken together, "constitute an adequate operational definition of a construct" (Polit and Beck 2006, p. 490) or "the extent to which an instrument adequately samples the research domain of interest when attempting to measure phenomena" (Wynd et al., 2003, p. 509). The content validity ratio proposed by Lawshe (1975) formed the basis for our analysis. This method involves soliciting the opinions of subject matter experts $(n=7)$ on the items in a survey. They are asked to rate each item on the scorecard from "essential", "useful" or "not necessary" on a three point scale. According to Lawshe (1975), if more than half the reviewers indicate that an item is essential, that item has some content validity. In light of this, only items that reached this target remained on the scorecard and the remaining items were removed.

\section{Construct Validity}

Construct validity measures the internal consistency of the instrument. Internal consistency explains the degree to which the items in a survey measure a similar concept (Tavakol and Dennick, 2011). Internal consistency is derived from the correlations between different items on the same test. It is used to assess whether several items that propose to measure the same general construct (e.g. fulfil the mandate, attention seeking, leadership, autonomy) produce similar scores. Cronbach's alpha provides a method of measuring construct validity or the internal consistency of a scale (Hensley, 1999). The higher the calculated value of Cronbach's alpha the more reliable the survey (Santos, 1999). Nunnally (2010) indicated 0.7 as an appropriate reliability co efficient, although different authors have proposed different cut off points for this value, 0.7 is the most widely accepted in the literature (Nunnally, 2010; Cortina, 1993; Hensley, 1999) and consequently this value was employed in our study. To ensure that the test was applied correctly guidance from the 'tau equivalent model' was followed (Tavakol and Dennick, 2011).
Manufacturing subsidiaries of American MNCs operating in the Medical Device industry in Ireland were targeted to generate data to measure the construct validity of the instrument in this study. The rationale for this selection was that such organisations were operating in a comparable market with similar challenges and our goal was to maintain an element of homogeneity in the sample. Probability sampling where each member of the population had a "known and usually equal chance of being included in the survey" was used in this research (Lewis et al., 2012, p. 261). The sample was random and stratified in order to ensure that it was representative of the population and to minimise selection bias. The use of strata "ensures high homogeneity within each stratum and heterogeneity between strata" (Forza, 2002, p.165). The two strata selected were engineers/technicians/scientists and managers. Each of these strata mutually exclusive following best practice (DeVellis, 2012). Proportional allocation was not undertaken. The instrument was distributed to 750 individuals in total. The instrument was accompanied by a cover letter detailing the rationale and goals of the survey. This letter stated that the results were for research purposes only and encouraged the participants to be as open and as frank as possible in order to minimise subject bias.

The values of alpha all exceeded 0.842 suggesting a strong internal consistency among the items being examined. It essentially showed that for each construct analysed, the respondents who tended to select strongly agree and agree for one question were also inclined to select strongly agree and agree for the other questions. Equally respondents who picked strongly disagree and disagree for one question tended to select similar scores for related question/s. This illustrates the reliability of the scorecard.

\section{Discussion}

Auditing has been championed as a useful exercise by a number of authors (Voss et al., 1994; Cormican and O'Sullivan, 2003). The scorecard allows organisations to gauge where they are in relation to best practice, identifying areas in which they are performing well and opportunities for improvement (Cormican and O'Sullivan, 2003). Such practices can also provide a company with a baseline to help review the company's continuous improvement initiatives. The instrument developed is an example of academic research being used to underpin improvements in identifying issues in business and driving progress (Chiesa et al., 1996).

The scorecard was created around research-based statements (Voss et al., 1994). Each item was designed to capture best practice for subsidiaries looking to secure role development and higher value added activities. It is a tool to allow an organisation to assess current versus best practice. Using proven theoretical concepts to evaluate the scorecard improved its integrity and this research employed face validity, content validity and construct validity. Findings from this analysis lead to the modification of certain items and the removal of others.

The scorecard presented here serves as a template. In order to implement the scorecard it should be customised to the organisation in question. To do this a case analysis could be undertaken to assess 
which of the strategies is being pursued and then a scorecard with only the relevant sections should be distributed. For both questions the subsidiary name must be included in order to adapt the questions to the case study organisation in question. The examples provided in certain questions should also be customised to the case study in question. For example, in question twenty six the example of manufacturing should be replaced with an example that accurately captures the mandate of the case study company being examined.

The overarching objective of this study has been to deepen our understanding of subsidiary role development. Our research analyses best practice for subsidiaries seeking to secure role development and higher value added activities in a dynamic networked environment through an open discursive perspective. Our work focused on identifying essential constructs and generating an integrated framework and operationalizing this in the form of a self-assessment instrument. This tool was then tested in a real world environment. This allows organizations to assess themselves against best practice as defined by the literature. Hence we respond to recent calls to investigate practical solutions and bridge the gap between theory and practice. From the survey results, it is clear than on the whole the instrument developed is accurate, reliable and valid. While it was specifically designed to be used as a standalone audit tool; there is potential for this survey to be rolled out across all subsidiaries in the multinational company. It could be used to benchmark both within multinational companies and between different subsidiaries and within industries. The tool can also be used to reassess the organisation once improvements have been made to establish if they have had the desired impact.

Our analysis makes important contributions to technology management research. Our findings contribute to research on subsidiary role evolution by identifying and testing critical constructs. Prior research recognizes that critical elements are essential to success and our findings add to this debate. These results allow us to advance the general theoretical development of the field and to empirically test previous explanations as to how subsidiaries of multinational corporations can generate innovative value adding strategies. These findings are useful in furthering our understanding of how implement best practice. Hence, this study is of managerial relevance to subsidiary managers. Certain limitations of this study should be noted. This study focused solely on multinational subsidiaries operating in the medical technology industry in a small open economy i.e. Ireland. Consequently, the context of this study is quite specific and the explanatory power of our findings may be limited to this particular industry or country. Future studies could strive to address this deficit.

\section{References}

Achcaoucaou, F., Miravitlles, P., and León-Darder, F. (2014). Knowledge sharing and subsidiary R\&D mandate development: A matter of dual embeddedness. International Business Review, 23 (1), 76-90.

Allen, I.E. and Seaman, C.A. (2007). Likert scales and data analyses. Quality Progress, 40, pp. 64-65.
Ambos, B., and Schlegelmilch, B.B. (2007). Innovation and control in the multinational firm: A comparison of political and contingency approaches. Strategic Management Journal, 28 (5), pp. 473-486.

Ambos, T.C., Andersson, U. and Birkinshaw, J. (2010). What are the consequences of initiative-taking in multinational subsidiaries. Journal of International Business Studies, 41, pp. 1099-1118.

Balogun, J., Jarzabkowski, P., and Vaara, E. (2011). Selling, resistance and reconciliation: A critical discursive approach to subsidiary role evolution in MNEs. Journal of International Business Studies, 42 (6), pp. 765-786.

Bevan, A. A., Estrin, S. and Meyer, K. E. (2004). Institution building and the integration of Eastern Europe in international production. International Business Review, 13, pp. 43-64.

Birkinshaw, J. and Hood, N. (1998). Multinational subsidiary evolution: capability and charter change in foreign-owned subsidiary, Academy of Management Review, 23 (4) pp. 773-795.

Birkinshaw, J. and Fry, N. (1998). Subsidiary initiatives to develop new markets. Sloan Management Review, 39, pp. 51-61.

Birkinshaw, J. (1997). Entrepreneurship in multinational corporations: The characteristics of subsidiary initiatives. Strategic Management Journal, 18, pp. 207-229.

Birkinshaw, J., Bouquet, C. and Ambos, T. (2006). Attention HQ. Business Strategy Review, 17, pp. 4-9.

Blazejewski, S. and Becker-Ritterspach, F. (2011). Conflict in headquarter-subsidiary relations: a critical literature review and new directions, C. Dörrenbächer, M. Geppert (Eds.), Politics and Power in the Multinational Corporation: The Role of Institutions, Interests and Identities, Cambridge University Press, Cambridge.

Bouquet, C. and Birkinshaw J. (2008a). Managing power in the multinational corporation: How low-power actors gain influence. Journal of Management, 34, pp. 477-508.

Bouquet, C. and Birkinshaw J. (2008b). Weight versus voice: How foreign subsidiaries gain attention from corporate headquarters. Academy of Management Journal, 51, pp. 577-601.

Boussebaa, M. (2009). Struggling to organize across national borders: The case of global resource management in professional service firms. Human Relations, 62, 6 pp. 829-850.

Cantwell, J. and Mudambi, R. (2005). MNE competence-creating subsidiary mandates. Strategic Management Journal, 26, pp. 1109-1128.

Cantwell, J. and Iguchi, C. (2005). Effects of backward linkages to local suppliers' development path: The case of the Malaysian electrical and electronics industry, A. Giroud, A.T. Mohr, D. Yang (Eds.), Multinationals and Asia: Organizational and institutional relationships, Routledge, London, New York (2005), pp. 54-71 
Chisea, V., Coughlan, P. and Voss, C.A. (1996). Development of a technical innovation audit. Journal of Product Innovation Management, 13, pp. 105-136.

Cormican, K. and O'Sullivan, D. (2003). A scorecard for supporting enterprise knowledge management. Journal of Information \& Knowledge Management, 2, (3), pp. 191-201.

Cortina, J.M. (1993). What is coefficient alpha? An examination of theory and applications. Journal of Applied Psychology, 78, 1, 98- 104.

Delany E. (2000). Strategic development of the multinational subsidiary through subsidiary initiative-taking. Long Range Planning, 33, pp. 220-244.

DeVellis, R.F. (2012). Scale development: Theory and applications (Vol. 26). Sage publications.

DeVon, H.A., Block, M.E., Moyle-Wright, P., Ernst, D.M., Hayden, S.J., Lazzara, D.J., Savoy, S.M. and Kostas-Polston, E. (2007). A psychometric toolbox for testing validity and reliability. Journal of Nursing scholarship, 39, pp. 155-164.

Di Minin, A. and Zhang, J. (2010). An exploratory study on international R\&D strategies of Chinese companies in Europe. Review of Policy Research, 27 (4), pp. 433-455

Dörrenbächer, C. and Gammelgaard, J. (2006). Subsidiary role development: The effect of micro-political headquarters-subsidiary negotiations on the product, market and value-added scope of foreignowned subsidiaries. Journal of International Management, 12, pp. 266-283.

Dutton, J.E. and Ashford, S.J. (1993). Selling issues to top management. Academy of Management Review, 18, pp. 397-428.

Dutton, J.E. and Ashford, S.J., O'Neill, R.M., Hayes, E. and Wierba, E.E. (1997). Reading the wind: How middle managers assess the context for selling issues to top managers. Strategic Management Journal, 18, (5), pp. 407 to 423

Fennelly, D. and Cormican, K. (2006). Value chain migration from production to product centred operations: an analysis of the Irish medical device industry. Technovation, 26, (1), pp. 86-94.

Forza, C. (2002). Survey research in operations management: a process-based perspective. International journal of operations \& production management, 22, pp. 152-194.

Garcia-Pont, C., Canales, J.I. and Noboa, F. (2009). Subsidiary strategy: The embeddedness component, Journal of Management Studies, 46, (2), pp. 182-214

Ghoshal, S. and Bartlett, C.A. (1990). The multinational corporation as an interorganizational network. Academy of Management Review, pp. 603-625.
Haladyna, T.M. (2004). Developing and validating multiple-choice test items, Routledge.

Hansen, M. W., Petersen, B., and Wad, P. (2011). Change of subsidiary mandates in emerging markets: The case of Danish MNCs in India. Transnational Corporations Review, 3, (2), pp. 104-116.

Hardesty, D.M. and Bearden, W.O. (2004). The use of expert judges in scale development: Implications for improving face validity of measures of unobservable constructs. Journal of Business Research, 57, pp. 98-107.

Heidenreich, M. (2012). The social embeddedness of multinational companies: a literature review. Socio-Economic Review, 10, pp. 549-579.

Hensley, R.L. (1999). A review of operations management studies using scale development techniques. Journal of Operations Management, 17, pp. 343-358.

Jindra, B., Giroud, A., and Scott-Kennel, J. (2009). Subsidiary roles, vertical linkages and economic development: Lessons from transition economies. Journal of World Business, 4, (2), pp. 67-179.

Lawshe, C.H. (1975). A quantitative approach to content validity. Personnel psychology, 28, pp. 563-575.

Lewis, P., Thornhill, A. and Saunders, M. (2012). Research Methods for Business Students $6^{\text {th }}$ Edition, Pearson Education: Harlow.

Luo, Y. (2005). Toward co-opetition within a multinational enterprise: A perspective from foreign subsidiaries, Journal of World Business, 40, (1), pp. 71-90

Mitchell, R.K., Agla, B.R. and Wood, D.J. (1997). Toward a theory of stakeholder identification and salience: Defining the principle of who and what really counts. Academy of Management Review, pp. 853-886.

Mudambi, R. and Navarra, P. (2004). Is knowledge power? Knowledge flows, subsidiary power and rent-seeking within MNCs. Journal of International Business Studies, 35, pp. 385-406.

Nunnally, J.C. (2010). Psychometric Theory 3E, Tata McGraw-Hill Education.

Paterson, S. and Brock, D.M. (2002). The development of subsidiarymanagement research: review and theoretical analysis. International Business Review, 11, pp. 139-163.

Persaud, A. (2005). Enhancing synergistic innovative capability in multinational corporations: an empirical investigation, Journal of Product Innovation Management, 22, pp. 412-429.

Polit, D. F., and Beck, C. T. (2006). The content validity index: are you sure you know what's being reported? Critique and recommendations. Research in nursing \& health, 29, (5), pp. 489-497. 
Reilly, M., Scott, P. and Mangematin, V. (2012). Alignment or independence? Multinational subsidiaries and parent relations. Journal of Business Strategy, 33, (2), pp. 4-11.

Santos, J.R.A. (1999). Cronbach's alpha: A tool for assessing the reliability of scales. Journal of Extension, 37, pp. 1-5.

Sargeant, L.W. (1990). Strategic planning in a subsidiary. Long Range Planning, 23, pp. 43-54.

Schmid, S., Dzedek, L. R., and Lehrer, M. (2014). From Rocking the Boat to Wagging the Dog: A Literature Review of Subsidiary Initiative Research and Integrative Framework. Journal of International Management, 20, (2), pp. 201-218.

Schotter, A., and Beamish, P. W. (2011). Performance effects of MNC headquarters-subsidiary conflict and the role of boundary spanners: The case of headquarter initiative rejection. Journal of International Management, 17, (3), pp. 243-259.

Scott, P., Gibbons, P. and Coughlan, J. (2010). Developing subsidiary contribution to the MNC-Subsidiary entrepreneurship and strategy creativity. Journal of International Management, 16, pp. 328-339.

Sofka, W., Shehu, E., and de Faria, P. (2014). Multinational subsidiary knowledge protection-Do mandates and clusters matter? Research Policy, 43, (8), pp. 1320-1333.

Tavakol, M. and Dennick, R. (2011). Making sense of Cronbach's alpha. International Journal of Medical Education, 2, pp. 53-55.

Tavares, A.T. and Young, S. (2006). Sourcing patterns of foreign-owned multinational subsidiaries in Europe. Regional Studies, 40, (6), pp. 583-600.
Tseng, C.H., Fong, C.M. and Su, K.H. (2004). The determinants of MNC subsidiary initiatives: implications for small business. International Journal of Globalisation and Small Business, 1, pp. 92-114.

Voss, C., Chisea, V. and Coughlan, P. (1994). Developing and testing benchmarking and self-assessment frameworks in manufacturing. International Journal of Operations \& Production Management, 14, pp. 83-100.

Wang, Y. and Suh, C.S. (2009). Towards a re-conceptualization of firm internationalization: heterogeneous process, subsidiary roles and knowledge flow, Journal of International Management, 15, pp. 447-459.

Worthington R.L. and Whitaker T.A. (2006). Scale development research a content analysis and recommendations for best practices. The Counseling Psychologist, 34, (6), pp. 806-838.

Wynd, C.A., Schmidt, B. and Schaefer, M.A. (2003). Two quantitative approaches for estimating content validity. Western Journal of Nursing Research, 25, pp. 508-518.

Yamin, M. and Andersson, U. (2011). Subsidiary importance in the MNC: What role does internal embeddedness play? International Business Review, 20 (2), pp. 151-162.

Young, S. and Tavares, A.T. (2004). Centralization and autonomy: Back to the future, International Business Review, 13 pp. 215-237.

Zeschky, M., Daiber, M., Widenmayer, B., and Gassmann, O. (2014). Coordination in global R\&D organizations: An examination of the role of subsidiary mandate and modular product architectures in dispersed R\&D organizations. Technovation, 34 (10), pp. 594-604. 
